Valery Derkach, DSc in Engineering Science, Director, Branch office of Institute BeINIIS RUE - Scientific-Technical Center (Brest, Belarus)

\title{
NUMERICAL STUDIES OF THE COEFFICIENT OF THE DEGREE OF PINCHING OF HOLLOW-CORE PRECAST SLABS IN STONE WALLS
}

(C) РУП “Институт БелНИИС", 2019

Institute BeINIIS RUE, 2019

\section{ABSTRACT}

The results of numerical studies of the degree of pinching of hollowcore precast slabs in the stone walls in the environment of the computing system "ANSYS" are presented. The numerical calculation of the junction of the floor slab joints with the bearing wall was carried out by the finite element method taking into account the contact interaction of the floor slabs with masonry. The theoretical values of the pinch point degree coefficient are compared with the results of physical studies of a fragment of reinforced concrete slab of prestressed multi-core hollowcore forged slabs with platform joints. The difference between the theoretical and experimental values of the degree of pinching did not exceed 12.5\%. Based on the numerical calculation, the dependences of the coefficient of the degree of pinching from the elastic modulus of the masonry guests and the magnitude of the compression stresses of the load-bearing walls, using which you can calculate the value of the reference bending moments arising in the floor slabs are obtained. It is shown that the coefficient of the degree of pinching $K$ non-linearly increases with an increase in the elastic modulus of masonry bearing walls. In this case, the greatest influence on the values of $K$ has a change in the modulus of elasticity in the range of 1200-6000 MPa. In the case of supporting the slabs on the walls, made of aerated concrete blocks through a monolithic reinforced concrete belt, the value of the coefficient $K$ increases 1.5 times. It has been established that the degree of pinching depends nonlinearly on the level of compressive stresses at the contact 
of the plate with the wall. At high levels of compression equal to 1-2 $M P a$, which are characteristic of the walls of the lower floors of multistorey buildings, the value of the degree of pinching is in the range of 0.65-0.81.

Keywords: hollow-core slabs, masonry, platform joint, contact interaction, support zone.

For citation: Derkach V. Numerical studies of the coefficient of the degree of pinching of hollow-core precast slabs in stone walls. Contemporary Issues of Concrete and Reinforced Concrete: Collected Research Papers. Minsk. Institute BelNIIS. Vol. 11. 2019. pp. 25-35. https://doi.org/10.35579/2076-6033-2019-11-02

Аеркач Валерий Николаевич, А-р техн. наук, Аиректор, Филиал РуП "Институт БелНИИС" - «Научно-технический центр" (г. Брест, Беларусь)

\section{ЧИСЛЕННОЕ ИССАЕАОВАНИЕ КОЭФФИЦИЕНТА СТЕПЕНИ ЗАЩЕМАЕНИЯ МНОГОПУСТОТНЫХ ЖЕЛЕЗОБЕТОННЫХ ПАИТ В КАМЕННЫХ СТЕНАХ}

\section{АННОТАЦИЯ}

Приведены результаты численных исследований коэффициента степени защемления многопустотных железобетонных плит в каменных стенах в среде вычислительного комплекса «ANSYS». Численный расчет узла сопряжения плит перекрытия с несущей стеной выполнялся методом конечных элементов с учетом контактного взаимодействия плит перекрытия с каменной кладкой. Выполнено сопоставление теоретических значений коэффициента степени защемления с результатами физических исследований фрагмента железобетонного перекрытия из предварительно напряженных многопустотных плит безопалубочного формования с платформенными стыками. Разница теоретических и экспериментальных значений коэффициента степени защемления 
не превысила 12,5 \%. На основании численного расчета получены зависимости значений коэффициента степени защемления от модуля упругости каменной кладки и величины напряжений обжатия несущих стен, с помощью которых можно рассчитать величину опорных изгибающих моментов, возникающих в плитах перекрытия. Показано, что коэффициент степени защемления $K$ нелинейно возрастает с увеличением модуля упругости каменной кладки несущих стен. При этом наибольшее влияние на значения К оказывает изменение модуля упругости в диапазоне 1200-6000 МПа. В случае опирания плит перекрытия на стены, выполненные из ячеистобетонных блоков, через монолитный железобетонный пояс значение коэффициента $К$ возрастает в 1,5 раза. Установлено, что коэффициент степени защемления нелинейно зависит от уровня сжимающих напряжений по контакту плиты со стеной. При высоких уровнях обжатия, равных 1-2 МПа, которые характерны для стен нижних этажей многоэтажных зданий, значение коэффищиента степени защемления находится в диапазоне 0,65-0,81.

Ключевые слова: многопустотные плиты, каменная кладка, платформенный стык, контактное взаимодействие, опорная зона.

Для цитирования: Деркач, В. Н. Численное исследование коэффициента степени защемления многопустотных железобетонных плит в каменных стенах / В. Н. Деркач // Проблемы современного бетона и железобетона : сб. науч. тр. / Ин-т БелНИИС; редкол.: О. Н. Лешкевич [и др.] - Минск, 2019. - Вып. 11. - С. 2535. https://doi.org/10.35579/2076-6033-2019-11-02

\section{INTRODUCTION}

When calculating the bearing stone walls according to the Construction Norms and Regulations (SNiP) II-22-81, the reinforcedconcrete hollow-core slabs are considered as self-supported beam elements. Such analytical model of floor slabs with adopted boundary conditions is certainly simplified. Actually, a bending moment causing the tension stresses at the top edge of the slab section appears on 
the supporting areas of the floor slabs due to unintended partial pinching of them in the walls. In the floor, slabs manufactured using the conveyor-type production process, the tension stresses in the top zone of the slab section are perceived jointly by the concrete and longitudinal top reinforcement. In the slabs formed without shuttering, the bending moment caused by the unintended pinching is actually perceived by the concrete section only, because the length of the zone of transmitting the stresses from the top prestressed reinforcement to concrete is about $180-220 \mathrm{~mm}$, while the depth of embedding of the floor slabs in the walls does not exceed $120 \mathrm{~mm}$. For this reason, wideopening cracks causing the collapse of slabs from shear at the support $[1,2]$ can appear in the zones near the supports of the slabs formed without shuttering embedded in the walls.

The ultimate state of the load-bearing ability of the supporting section of the floor slab embedded in the stone wall may be checked subject to the data on the mobility of joint of conjugation of the slab with the wall, which is assessed usually by the coefficient of degree of pinching $\mathrm{K}$ that is equal to the ratio of the actual value of the bending moment to the theoretical value of the support moment calculated from the condition of rigid pinching of the floor slab on the support. It is known that the mobility of the joints of conjugation of the floor slab with the walls depends on the depth of embedding the slabs in the wall, compression stresses, rigidly characteristics of the material of being walls and angles of rotation of the supporting sections of the slabs. The influence of the said parameters on the coefficient of degree of pinching was investigated on the basis of physical experiments, which were performed as a rule on the samples with actual dimensions due to impossibility of scale-model study [3-5]. Since the full-scale testing are laborious and expensive and, above all, parametrically limited, the numerical experiment with application of verified computed models are efficient supplements to the physical experiments. This article presents the technique and results of the numerical studies of the values of the coefficient of degree of pinching of hollow-core slabs in bearing stone walls as the compression stress in the walls and deformation characteristics of the masonry materials vary. 


\section{COMPUTED MODEL OF THE JUNCTION OF THE FLOOR SLAB WITH THE LOAD-BEARING WALL}

The numerical computation of the junction of the floor slabs with the load-bearing wall was performed by the finite-element method (FEM) in the environment of the ANSYS computer complex. In the course of computation, the nonlinear contact problems were solved taking into account the rubbing and cohesion between the masonry and reinforced-concrete floor slab. In finite-element models, the finite elements and models of materials were accepted from the software complex library. The linear elastic stage of work of the hollow-core slab was considered before formation of opening-mode racks in it. The masonry was considered as homogeneous (uniform) material endowed with generalized deformation characteristics of masonry products and mortar joints, which were determined from the results of the previously performed tests of the masonry samples in the simple kinds of stressed state [6] (Table 1).

Table 1

Deformation characteristics of masonry

\begin{tabular}{|l|c|c|}
\hline \multicolumn{1}{|c|}{ Masonry type } & $\begin{array}{c}\text { Modulus of } \\
\text { elasticity Ei (MPa) }\end{array}$ & Poison's ratio \\
\hline Solid ceramic bricks on standard mortar & 11,150 & 0.22 \\
\hline $\begin{array}{l}\text { Ceramic bricks with hollowness V=18\% on } \\
\text { standard mortar }\end{array}$ & 6,600 & 0.36 \\
\hline Silicate blocks on thin-joint mortar & 4,100 & 0.13 \\
\hline Silicate blocks on polyurethane foam adhesive & 3,300 & 0.30 \\
\hline $\begin{array}{l}\text { Cellular-concrete blocks D500, B3.0 on thin-joint } \\
\text { mortar }\end{array}$ & 1,240 & 0.13 \\
\hline
\end{tabular}

When simulating, the hollow-core slabs with the span of $6 \mathrm{~m}$ from the one side were supported by the load-bearing wall over the length of $120 \mathrm{~mm}$ while the hinge support was simulated on the other side of the slabs. A layer of M100 sand-cement mortar with the thickness of $15 \mathrm{~mm}$ was located between the top and bottom edges of the floor slab and the masonry. The modulus of elasticity of cement-sand mortar 
placed between the slab and the masonry was set to $10,500 \mathrm{MPa}$ and the Poison's ratio to 0.15 [7]. The values of the friction ratio between the cement-sand mortar layer, floor slab and masonry was set to 0.6; the tangential adhesion strength was assigned depending on the kind of masonry according to the results of the tests [8]. The slabs were loaded with gravitation load distributed uniformly and equal to $8 \mathrm{KPa}$. The value of compressing stresses acting perpendicularly to horizontal joints over the top edge of the wall was varied within the range 0.3-2 $\mathrm{MPa}$. Over the bottom edge of the wall, the bonds were superimposed on the motions along the axes $\mathrm{X}, \mathrm{Y}, \mathrm{Z}$ over the top one - on motions along the $\mathrm{X}$ and $\mathrm{Z}$ axes. The computed model with the floor slabs is shown in Figure 1.

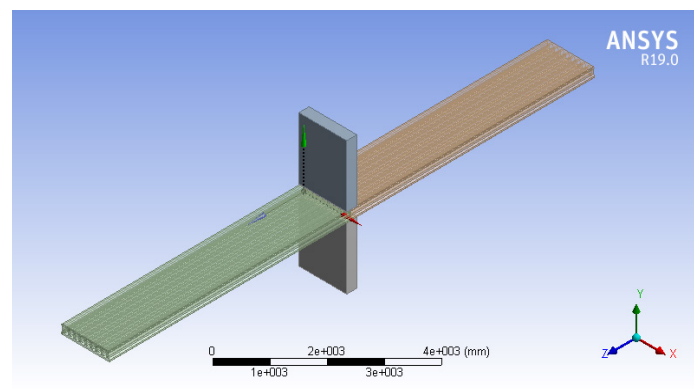

Figure 1. Computed model of the junction of the floor slab with the load-bearing wall

The computed model shown in Figure 2 corresponds to the pattern of tests of platform joints of the floor slabs formed without shuttering with the walls, which was implemented in paper [4].

\section{NUMERICAL ANALYSIS RESULTS}

To determine how credibly does the computed model of the junction of the floor slab with the wall reflect its real work, the experimental data results on the distribution of the bending moments over the length of the floor fragment presented in paper [5], were compared with the results of the numerical calculation of the finite-element model.

The numerical calculations have resulted in obtaining the deformed models of the junction of the floor slabs with the walls (Figure 2) as 
well as values and trajectories of the main tension stresses $\sigma_{1}$ over the top edge of the floor slab in case of partial unintended and rigid connection, according to which the maximum valued of bending moments appearing in the supporting section of the slab (Table 2).

a)

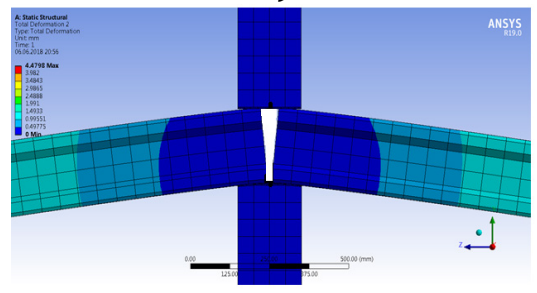

b)

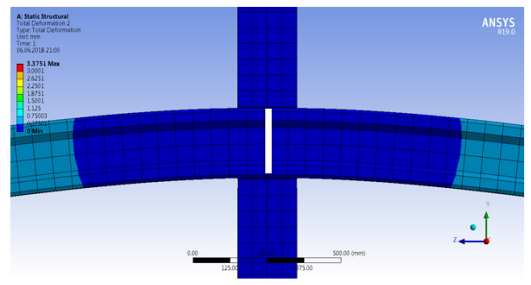

Figure 2. Deformed pattern of the model: a) partial unintended pinching of the slab, b) rigid pinching of the slab

Table 2

Comparison of maximum values of the support moments obtained experimentally and by numerical calculation

\begin{tabular}{|c|c|c|c|}
\hline Parameter to be compared & $\begin{array}{c}\text { Experimental } \\
\text { values } \\
\text { Mexp,kNm }\end{array}$ & $\begin{array}{c}\text { Theoretical values, } \\
\text { Mtheor,kNm }\end{array}$ & $\begin{array}{c}\text { Deviation } \\
\%\end{array}$ \\
\hline Partial unintended fixation & 35 & 31.96 & 9.5 \\
\hline Rigid fixation & 55 & 57.17 & 3.9 \\
\hline Coefficient of degree of pinching & 0.64 & 0.56 & 12.5 \\
\hline
\end{tabular}

The comparison of the experimental and theoretical values of the support moments is an evidence of their satisfactory matching that allows making a conclusion on the adequacy of the computed model shown in Figure 2 and expediency of its application for assessment of the stress-strain behaviour (SSB) of the junctions of the floor slabs with stone walls.

On the basis of the numerical calculation of the finite-element model, the maximum values of bending moments in the support sections of the slab with rigid $M_{\text {bonded }}$ and partial unintended $M_{\text {frictional }}$ its pinching in the 
load-bearing wall depending on the deformation characteristics of the masonry (see Table 1) and vertical clamping pressure of $0.3 \mathrm{MPa}$. The results of calculations are presented in Table 3.

Table 3

\section{Maximum values of the bending moments in the support section of the floor slab obtained by the numerical calculation}

\begin{tabular}{|l|c|c|c|}
\hline \multicolumn{1}{|c|}{ Masonry type } & $\begin{array}{c}\text { M frictional, } \\
\mathbf{k N m}\end{array}$ & $\begin{array}{c}\text { M,bonded, } \\
\mathbf{k N m}\end{array}$ & $M_{\text {frictional }} / M_{\text {bonded }}$ \\
\hline Solid ceramic bricks on standard mortar & 12.74 & 52.55 & 0.24 \\
\hline $\begin{array}{l}\text { Ceramic bricks with hollowness V=18\% on } \\
\text { standard mortar }\end{array}$ & 11.36 & 50.6 & 0.23 \\
\hline Silicate blocks on thin-joint mortar & 9.3 & 48.29 & 0.19 \\
\hline $\begin{array}{l}\text { Silicate blocks on polyurethane foam } \\
\text { adhesive }\end{array}$ & 8.59 & 47.58 & 0.18 \\
\hline $\begin{array}{l}\text { Cellular-concrete blocks D500, B3.0 on thin- } \\
\text { joint mortar }\end{array}$ & 7.24 & 46.86 & 0.15 \\
\hline
\end{tabular}

The graphical interpretation of the obtained results is shown in Figure 3.

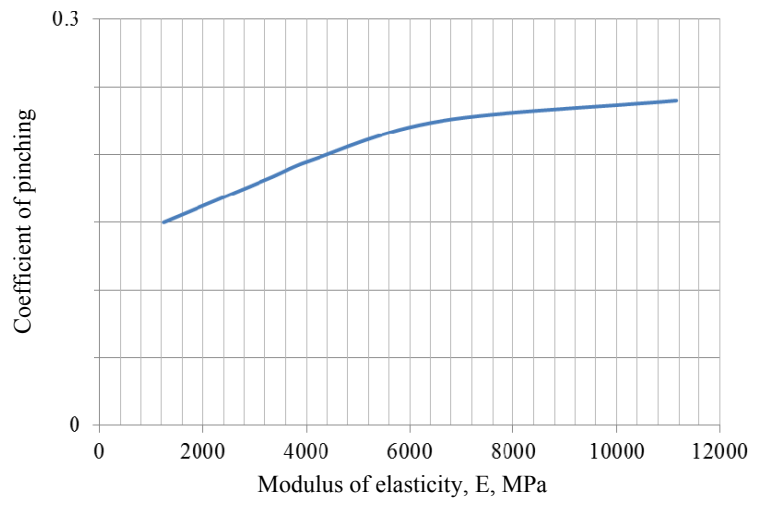

Figure 3. Dependence of the coefficient of degree of pinching on the modulus of elasticity of the masonry

As follows from Figure 3 the coefficient of the degree of pinching $\mathrm{K}$ increases with the increase of the elastic modulus of masonry loadbearing walls. The K-E dependence has non-linear nature. The greatest 
influence on the values of $\mathrm{K}$ has a change in the $\mathrm{E}$ value in the range of 1,200-6,000 MPa. If the floor slabs are supported by the walls built of materials having high stress-strain behavior and low strength of, for example, cellular-concrete blocks, the reaction is transmitted from the floor slabs to the walls through the monolithic reinforcedconcrete block. The calculations show that the value of the coefficient $\mathrm{K}$ increases about 1.5 times in this case.

To assess the influence of the compressing stresses over the contact of the slab with the wall by the value of the coefficient of degree of pinching $K$, the analysis of the strain and stress state of the platform joint of the floor slab with the masonry with the compression stress values $\sigma_{c, l o c}=1 ; 1,5 ; 2 \mathrm{MPa}$, which are typical for the load-bearing walls of lower floors of 9-12-storeyed buildings. The platform joint of the slab formed without shuttering with the supporting depth $l_{\text {sup }}=120$ $\mathrm{mm}$ and vertical elements of masonry made of ceramic bricks with the hollowness $V=18 \%$. The diagram of dependence of the coefficient of degree of pinching of the floor slabs $K$ on the vertical compression stresses in the walls $\sigma_{\text {c,loc }}$ obtained from the results of the numerical calculation is shown in Figure 4.

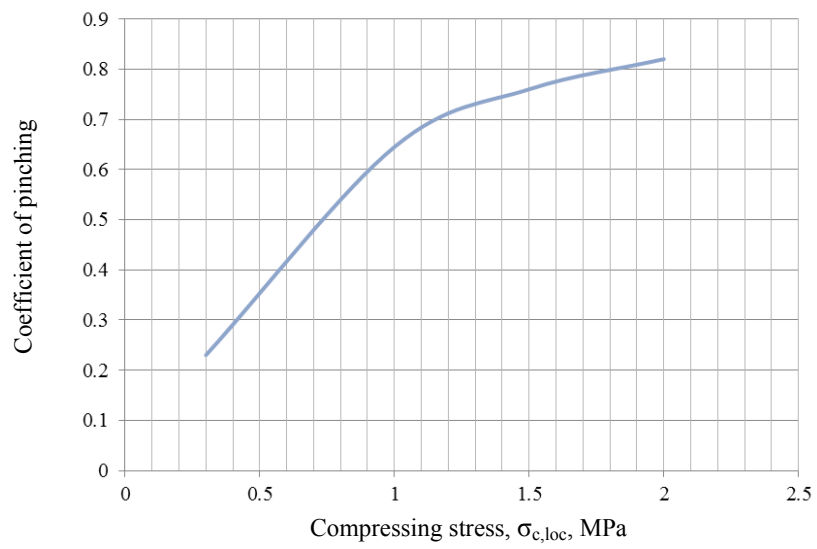

Figure 4. Diagram of dependence of the coefficient of degree of pinching $K$ on the level of compressing stresses over the contact of the slab with the wall $\sigma_{c, \text { loc }}$

As follows from Figure 4, the degree of pinching $K$ depends nonlinearly on the level of compressive stresses at the contact of the slab with the wall. At high levels of compression $\left(\sigma_{\mathrm{c}, \mathrm{loc}}=1-2 \mathrm{MPa}\right)$, which are 
characteristic of the walls of the lower floors of multi-storey buildings, the $K$ value is within the range of $0.65-0.81$.

It should be noted that the $\sigma_{c, l o c}-\mathrm{K}$ dependence obtained by the numerical calculation has satisfactory qualitative and quantitative matching with the results of experimental investigations [4], according to which the $\mathrm{K}$ value for slabs supported by the load-bearing walls built of ceramic bricks at $\sigma_{c, l o c}=1-2 \mathrm{MPa}$ is $0.6-0.66$. Higher values of the $\mathrm{K}$ coefficient obtained by the finite-element model calculation are explained by the fact that the idealized computed model does not take into account defects, which appear when manufacturing the experimental samples of platform joints of the floor slabs with the load-bearing walls, as well as non-linear work of the masonry.

\section{CONCLUSIONS}

1. The values of coefficients of degree of pinching of hollow-core slabs in stone walls $K$ obtained by the numerical calculation of the finite-element model taking into account the contact interaction of the floor slabs with the masonry correlate satisfactorily with the data of physical experiments. The maximum deviation of theoretical and experimental values $K$ is $19 \%$.

2. The coefficient of degree of pinching $\mathrm{K}$ depends nonlinearly on the modulus of elasticity of the masonry $E$ and level of the compressing stresses over the contact of the slab with the wall $\sigma_{c, l o c}$. The "K-E" and " $\mathrm{K}-\sigma_{\mathrm{c}, \mathrm{loc}}$ " dependences enabling the determination the values of $K$ and support moments appearing in the floor slabs were obtained.

\section{REFERENCES}

1. Tur V. V., Petsold T. M., Shcherbach A. V. Stroitelnaya nauka i tekhnika. 2010. No 1-2. pp. 15-24. (rus)

2. Derkowski W. (2014) Niezamierzony efekt częściowego zamocowania stropów ze sprężonych płyt kanałowych. Przeglad budowlany. 2014. No 1. pp. 24-27.

3. Shmukler V. S. Stoyanov Ye. G., Pustovoytova O. M., Tertichniy Ye. N., Lvovskiy I. G., Korenev R. V. Komunalne gospodarstvo mist. 2014. Vypusk 114. pp. 22-31. (rus) 
4. Predvaritelno napryazhennyye zhelezobetonnyye mnogopustotnyye paneli perekrytiy zdaniy [Pre-stressed reinforced concrete hollow core floor slab panels]. M.: Stroitelstvo i arkhitektura. Seriya 8. Stroitelnyye konstruktsii. Obzornaya informatsiya. 1984. 77 p. (rus)

5. Lazovskiy A. D. Soprotivleniye izgibu mnogopustotnykh plit perekrytiy bezopalubochnogo formovaniya $v$ sostave platformennykh stykov zdaniy [Resistance to bending of precast prestressed hollow-core slabs in platform joints of buildings]: dis.... kand. tekhn. nauk. Novopolotsk: UO «Polotskiy gosudarstvennyy universitet». 2017. 150 p. (rus)

6. Derkach V. N. Stroitelstvo i rekonstruktsiya. 2012. No 2 (40). pp. 3-11. (rus)

7. Pangayev V. V. Razvitiye raschetno-eksperimentalnykh metodov issledovaniya prochnosti kladki kamennykh konstruktsiy [Development of calculation and experimental methods for studying the strength of masonry stone structures]: avtoref. dis. ... dokt. tekhn. nauk. Novosibirsk: NGASU (SIBSTRIN). 2009. 34 p. (rus)

8. Derkach V. N. Inzhenerno-stroitelnyy zhurnal. 2012. No 3 (29). pp. 19-28. (rus)

Received: 25.11.2019 